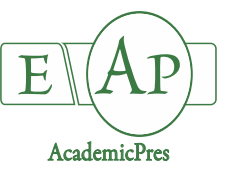

Tejeda-Sartorius O et al. (2021)

Notulae Botanicae Horti Agrobotanici Cluj-Napoca

Volume 49, Issue 2, Article number 12211

DOI: $10.15835 /$ nbha 49212211

Research Article

\title{
Fertilization methods and substrate particle size differentially affect growth and macronutrient status of Laelia anceps subsp. anceps
}

\author{
Olga TEJEDA-SARTORIUS, Yolanda L. FERNÁNDEZ-PAVÍA, \\ Maria G. PERALTA-SÁNCHEZ, Libia I. TREJO-TÉLLEZ*
}

College of Postgraduates in Agricultural Sciences Campus Montecillo, Montecillo, State of Mexico, Mexico; olgats@colpos.mx; mapale1@colpos.mx; mgperalta@colpos.mx; tlibia@colpos.mx ("corresponding author)

\begin{abstract}
The effects of three fertilization methods (FM) using the Peters Professional ${ }^{\circ} 30 \mathrm{~N}-10 \mathrm{P}-10 \mathrm{~K}$ water soluble fertilizer were analyzed: fertilization in irrigation water (FIW), foliar fertilization (FF), and their combination (FIW + FF), as well as two substrate particle sizes (SuPS): larger particle size (LPS) and smaller particle size (SPS), on the growth and macronutrient status of Laelia anceps subsp. anceps (Orchidaceae). A 3 $\times 2$ factorial experiment was established. Aerial and root growth, dry weight and concentration of macronutrients $\mathrm{N}, \mathrm{P}, \mathrm{K}, \mathrm{Ca}$, and $\mathrm{Mg}$ in leaves, pseudobulbs, and roots were all evaluated. The interaction of the study factors resulted in a greater number of leaves, while by simple effects, greater leaf area, number of pseudobulbs, root volume, and dry matter of leaves and roots were obtained, when FIW and LPS were used. With FF, greater growth in root volume was observed. There were no differences in the concentration of $\mathrm{N}$ in the growth organs analyzed, but due to the interaction of factors, a higher concentration of $\mathrm{P}, \mathrm{K}, \mathrm{Mg}$, and $\mathrm{S}$ was observed in roots, mainly with FIW + FF and SPS; although for P, there was a higher concentration in FIW and LPS. In the case of SPS, the concentrations of $K$ and $S$ were higher in leaves, and in pseudobulbs $P, K, C a$, $\mathrm{Mg}$, and $\mathrm{S}$ were higher. The results showed that there are positive effects on plant growth when FIW and LPS are used, while higher concentrations of nutrients in leaves, pseudobulbs and mainly in roots are observed when using SPS.
\end{abstract}

Keywords: foliar fertilization; growth parameters; nutrient uptake; orchid nutrition; orchid substrates

\section{Introduction}

The Orchidaceae is one of the most diverse families within the plant kingdom, encompassing approximately 24,500 species (Dressler, 2005) and 736 genera (Chase et al., 2015). Its wide diversity in sizes, shapes and colours has made these species one of the most valuable flower producing plants worldwide. Despite the wide diversity of species with ornamental potential, only a few genotypes dominate the global orchid market. Since megadiverse countries possess a wealth of orchids, proper protocols for the propagation and production of their species have to be carried out, which may result in economic benefits, integrate a diversity of floricultural products into the commercial chain, and discourage the looting of wild materials from their

Received: 05 Jan 2021. Received in revised form: 17 Jun 2021. Accepted: 17 Jun 2021. Published online: 23 Jun 2021.

From Volume 49, Issue 1, 2021, Notulae Botanicae Horti Agrobotanici Cluj-Napoca journal uses article numbers in place of the traditional method of continuous pagination through the volume. The journal will continue to appear quarterly, as before, with four annual numbers. 
natural habitats. As a megadiverse country, Mexico has launched this type of initiative to propagate and produce diverse orchids in sustainable environments (Tejeda-Sartorius et al., 2017).

Substrate management and nitrogen $(\mathrm{N})$ fertilization in ornamental orchids are key factors determining the success of orchid production systems (Zong-min et al., 2012). However, the mechanisms of nutrient uptake in wild epiphytic orchids are not entirely known, while the effects of the form and concentration of $\mathrm{N}$ on growth and flowering of orchids are poorly understood (Zhang et al., 2018). For Phalaenopsis, the most studied genus of orchids, an adequate supply of $\mathrm{N}$ is recommended, both in vegetative and reproductive stages to achieve the best growth and flowering (Wang and Chang, 2017).

The uptake of water-soluble nutrients by the leaves is generally not very efficient and does not play a very important role in the growth of plants in their natural habitats. Nevertheless, in cultivated species, foliar application of fertilizers can provide nutrients during critical phases (Mengel, 2002). The process of nutrient absorption by the leaves is different from that of the roots because the cell walls of the leaves are covered by a cuticle, which is not found in the root structure (Fageria et al., 2009). Leaf cuticles are known to be permeable to some ions in varying degrees (Kannan, 2010).

The root nutrient application method is more common and effective for nutrients required in larger amounts. However, under certain circumstances, foliar fertilization is more economical, effective, and environmentally friendly (Fageria et al., 2009; Kannan, 2010; Trejo-Téllez et al., 2016). Currently, there is a dire need to decrease the use of mineral fertilizers applied to the soil, such as $\mathrm{N}$, phosphorus $(\mathrm{P})$, and potassium (K) (Haytova, 2013), due to the high amounts of these plant nutrients leached when crops are over-fertilized (Kannan, 2010).

Both root and foliar applications of fertilizers are common agronomic practices among orchid growers, but just how efficient the processes of nutrient absorption and assimilation are with these methods is not completely known (Ruamrungsri et al., 2014). This lack of information is due, at least in part, to factors such as growth conditions, environment, and genotypes of orchids tested.

Epiphytic orchids generally need a coarse growing medium, which ideally also has to be open, welldrained, moisture-and nutrient-conserving, stable, and preferably low-cost (Slump, 2004; Wang et al., 2007). Plant age, development of the root system and its stability in the container are other factors affecting nutrient uptake and assimilation. Hence, large plants with thick roots need thicker mixes of substrates than those with finer roots. Moreover, young plants need a substrate mixture capable of retaining more moisture than when they become mature plants (Slump, 2004). Indeed, growing media with smaller particle sizes can promote better contact of roots with water and nutrients (Wang and Gregg, 1994). In terms of cheap and biodegradable materials, bark brings economic and environmental advantages as compared to other materials, such as rockwool and peat moss (Naasz et al., 2009). Pine bark is the most widely used substrate for orchid production, and it is frequently mixed with other components such as perlite, different types of peat, coconut fiber, diatomite, rockwool, etc. (Wang et al., 2007; Hwang and Jeong, 2007; Lichty et al., 2015; Kim et al., 2016). However, there is still little information about the size of the substrate particles and their influence on growth and nutrient retention capacity in orchids, depending on their growth stage.

Currently, we are developing models in order to establish optimal nutrient and agronomic management practices for the wild orchid species Laelia anceps subsp. anceps, with floral characteristics highly coveted in ornamental horticulture. Herein we evaluated: i) the effect of different fertilization methods: fertilization in irrigation water (FIW), foliar fertilization (FF), and the combination of both (FIW + FF), as well as two sizes of substrate particles: larger (LPS) and smaller particle size (SPS), on growth and macronutrient status of Laelia anceps subsp. anceps. 


\section{Materials and Methods}

\section{Plant material and treatments}

This study was carried out in an experimental orchid nursery located at the College of Postgraduates in Agricultural Sciences, Campus Montecillo, under the following environmental conditions: (in the maximum, minimum and average order): Temperature $\left({ }^{\circ} \mathrm{C}\right): 30.8,11.2,18.6$; relative humidity (\%): 94.4, 33.4, 70.6; and an average photosynthetic photon flux (PPF): $75.4 \mu \mathrm{mol} \mathrm{m}^{-2} \mathrm{~s}^{-1}\left(\mathrm{HOBO}\right.$ ware Pro $\left.{ }^{\circ}\right)$.

Seedlings of Laelia anceps subsp. anceps in vegetative stage, with $3 \pm 1$ pseudobulbs were used. They were propagated in vitro by Orquídeas Río Verde ${ }^{\circ}$ S. R. L. M. I., where they were purchased.

A $3 \times 2$ factorial experiment was established, where the first study factor was the fertilization method, with three levels: fertilization in irrigation water (FIW), foliar fertilization (FF), and the combination of both forms (FIW + FF); the second factor was the particle size of the substrate components (SuPS), consisting of pine bark (PB; Ecorteza ${ }^{\circ}$ ) and perlite (P), (PB 75\%: P 25\% v/v) with two levels: larger particle size (LPS) and smaller particle size (SPS). The sizes are described in Table 1.

Table 2 shows the physical and chemical properties of the substrates used.

Table 1. Treatments derived from different fertilization methods and particle size in the substrate for Laelia anceps subsp. anceps

\begin{tabular}{|c|c|c|}
\hline \multirow{2}{*}{ Treatments } & \multicolumn{2}{|c|}{ Description } \\
\hline & Fertilization Methods (FM) & Substrate particle sizes (SuPS) \\
\hline FIW with LPS & Fertilization in irrigation water (FIW) & $\begin{array}{c}\text { Larger particle size (LPS) } \\
\mathrm{PB}=13 \mathrm{~mm} ; \mathrm{P}=6 \mathrm{~mm}\end{array}$ \\
\hline FIW with SPS & Fertilization in irrigation water (FIW) & $\begin{array}{l}\text { Smaller particle size (SPS) } \\
\qquad \mathrm{PB}=4 \mathrm{~mm} ; \mathrm{P}=2 \mathrm{~mm}\end{array}$ \\
\hline FF with LPS & Foliar fertilization (FF) & $\begin{array}{l}\text { Larger particle size (LPS) } \\
\mathrm{PB}=13 \mathrm{~mm} ; \mathrm{P}=6 \mathrm{~mm}\end{array}$ \\
\hline FF with SPS & Foliar fertilization (FF) & $\begin{array}{l}\text { Smaller particle size (SPS) } \\
\qquad \mathrm{PB}=4 \mathrm{~mm} ; \mathrm{P}=2 \mathrm{~mm}\end{array}$ \\
\hline FIW + FF with LPS & $\begin{array}{c}\text { Fertilization in irrigation water }(\mathrm{FIW})+ \\
\text { Foliar fertilization }(\mathrm{FF})\end{array}$ & $\begin{array}{l}\text { Larger particle size (LPS) } \\
\mathrm{PB}=13 \mathrm{~mm} ; \mathrm{P}=6 \mathrm{~mm}\end{array}$ \\
\hline FIW + FF with SPS & $\begin{array}{c}\text { Fertilization in irrigation water }(\mathrm{FIW})+ \\
\text { Foliar fertilization }(\mathrm{FF})\end{array}$ & $\begin{array}{l}\text { Smaller particle size (SPS) } \\
\qquad \mathrm{PB}=4 \mathrm{~mm} ; \mathrm{P}=2 \mathrm{~mm}\end{array}$ \\
\hline
\end{tabular}

PB: Pine bark; P: Perlite

Table 2. Physical and chemical properties of the substrates used in this research

\begin{tabular}{|c|c|c|}
\hline \multirow{2}{*}{ Parameter } & \multicolumn{2}{|c|}{ Substrates } \\
\hline & LPS: PB $13 \mathrm{~mm}$ and P $6 \mathrm{~mm}$ & SPS: PB $4 \mathrm{~mm}$ and P $2 \mathrm{~mm}$ \\
\hline RAW (\%) & 11.55 & 24.05 \\
\hline EAW (\%) & 7.55 & 15.35 \\
\hline RW (\%) & 4.00 & 8.7 \\
\hline Bulk density $\left(\mathrm{g} \mathrm{cm}^{-3}\right)$ & 0.14 & 0.16 \\
\hline $\mathrm{pH}$ & 3.41 & 4.17 \\
\hline $\mathrm{EC}\left(\mathrm{dS} \mathrm{m}^{-1}\right)$ & 0.53 & 0.26 \\
\hline $\mathrm{OM}(\%)$ & 58.83 & 58.83 \\
\hline $\mathrm{N}\left(\mathrm{g} \mathrm{kg}^{-1}\right)$ & 1.29 & 1.17 \\
\hline $\mathrm{P}\left(\mathrm{mg} \mathrm{kg}^{-1}\right)$ & 34.51 & 30.39 \\
\hline $\mathrm{K}\left(\mathrm{cmol}_{\mathrm{c}} \mathrm{kg}^{-1}\right)$ & 0.53 & 0.34 \\
\hline $\mathrm{Ca}\left(\mathrm{cmol}_{\mathrm{c}} \mathrm{kg}^{-1}\right)$ & 7.00 & 8.20 \\
\hline $\mathrm{Mg}\left(\mathrm{cmol}_{\mathrm{c}} \mathrm{kg}^{-1}\right)$ & 6.00 & 6.20 \\
\hline $\mathrm{Na}\left(\mathrm{cmol}_{\mathrm{c}} \mathrm{kg}^{-1}\right)$ & 0.71 & 0.95 \\
\hline
\end{tabular}


Tejeda-Sartorius O et al. (2021). Not Bot Horti Agrobo 49(2):12211

\begin{tabular}{|l|c|c|}
\hline CEC $\left(\mathrm{cmol}_{\mathrm{c}} \mathrm{kg}^{-1}\right)$ & 60.16 & 48.32 \\
\hline $\mathrm{Fe}\left(\mathrm{mg} \mathrm{kg}^{-1}\right)$ & 149.89 & 197.65 \\
\hline $\mathrm{Cu}\left(\mathrm{mg} \mathrm{kg}^{-1}\right)$ & 27.97 & 25.78 \\
\hline $\mathrm{Zn}\left(\mathrm{mg} \mathrm{kg}^{-1}\right)$ & 9.96 & 10.20 \\
\hline $\mathrm{Mn}\left(\mathrm{mg} \mathrm{kg}^{-1}\right)$ & 39.49 & 39.30 \\
\hline $\mathrm{B}\left(\mathrm{mg} \mathrm{kg}^{-1}\right)$ & 1.13 & 0.22 \\
\hline
\end{tabular}

LPS: Larger particle size; SPS: Smaller particle size; RAW: Readily available water; EAW: Easily available water; RW:

Reserve water; EC: Electric Conductivity; OM: Organic Matter; CEC: Cation Exchange Capacity; Capacity; PB: Pine

bark; P: Perlite

In all three fertilization methods, $1 \mathrm{~g}$ of Peters Professional ${ }^{\circ} 30 \mathrm{~N}-10 \mathrm{P}-10 \mathrm{~K}$ water soluble fertilizer (equivalent to 300,100 , and $100 \mathrm{mg} \mathrm{L}^{-1} \mathrm{~N}, \mathrm{P}$ and $\mathrm{K}$, respectively) was applied. For foliar fertilization, $1 \mathrm{~mL}$ Aderatsa $\mathrm{L}^{-1}$ as surfactant was applied to the spray solution and mixed thoroughly prior to the foliar application.

In plants treated with FIW, $100 \mathrm{~mL}$ per pot were applied; for FF, a fine nozzle spray pump was used to give a gentle mist, and it was sprayed on the leaves, completely covering them with the nutrient solution, until a drip from the leaves was observed. For FIW + FF the applications were made alternately, that is, one week through irrigation, and the following week to the aerial part. Both forms of fertilization were made every 7 days in the evening (between 5:00 p.m. and 6:00 p.m.). Prior to the application of the nutrient solutions, the substrate was irrigated with tap water, as well as the next day after the application, to avoid accumulation of salts, both on the substrate and on the leaves.

\section{Studied variables and data analysis}

After six months of treatment application we evaluated both aerial growth parameters: number of leaves (NL) and pseudobulbs (NPSB), leaf area (LA; LICOR ${ }^{\circ}$ model LI-3000, Lincoln, NE, USA); as well as root growth parameters: number (NR), length (RL) and volume (RV) of roots. Subsequently, three plants per treatment were sampled and they were separated into their different organs: leaves, pseudobulbs, and roots. Once separated, the organs were dried in an oven with forced air circulation (Riossa HCF-125D, Mexico) at $70^{\circ} \mathrm{C}$ for $72 \mathrm{~h}$, to determine their dry biomass (OHAUS Pioneer ${ }^{\circ}$ Plus Precision PA3202, USA).

The concentrations of the macronutrients $\mathrm{N}, \mathrm{P}, \mathrm{K}, \mathrm{Ca}, \mathrm{Mg}$, and $\mathrm{S}$ were determined in dry leaf, pseudobulb, and root tissue. Total $\mathrm{N}$ analysis was carried out using the semi-micro-Kjeldahl method according to Bremner (1965). The concentration of the rest of the macronutrients was determined by wet digestion of the dry tissue with a mixture of perchloric and nitric acids, described by Alcántar and Sandoval (1999); the samples were analyzed in an inductively coupled plasma optical emission spectrometer (Agilent 725 Series ICPOES, Australia).

With the data obtained, an analysis of variance (ANOVA) was performed, and means were compared using Tukey's test $(\alpha=5)$, with the SAS statistical package (SAS, 2011).

\section{Results}

\section{Growth parameters}

Table 3 shows the significance of the study factors and their interaction in the evaluated growth variables. The interaction of the study factors significantly influenced the number of leaves, whereas the fertilization method significantly affected the number of pseudobulbs, leaf area, root volume, as well as dry biomass of both leaves and roots. The substrate particle size (SuPS) influenced number of leaves, leaf area, root volume, as well as dry biomass of both leaves and roots. 
Table 3. Statistical significance $(p)$ of the study factors, fertilization method and particle size in the substrate, as well as their interaction, on the growth parameters of Laelia anceps subsp. anceps plants

\begin{tabular}{|c|c|c|c|c|c|}
\hline Variation source & $\begin{array}{c}\text { Number o } \\
\text { leaves }\end{array}$ & $\begin{array}{l}\text { Numb } \\
\text { pseudo }\end{array}$ & & $\begin{array}{l}\text { eaf } \\
\text { rea }\end{array}$ & $\begin{array}{l}\text { mber of } \\
\text { oots }\end{array}$ \\
\hline Fertilization method (FM) & $0.1133 \mathrm{~ns}$ & 0.032 & & $183^{*}$ & $198 \mathrm{~ns}$ \\
\hline Substrate particle size (SuPS) & $0.0008^{*}$ & 0.106 & & $053^{*}$ & $401 \mathrm{~ns}$ \\
\hline $\mathrm{FM} \times \mathrm{SuPS}$ & $0.0122^{*}$ & 0.093 & & $13 \mathrm{~ns}$ & $172 \mathrm{~ns}$ \\
\hline \multirow{2}{*}{ Variation source } & \multirow{2}{*}{ Root length } & \multirow{2}{*}{ Root volume } & \multicolumn{3}{|c|}{ Dry biomass } \\
\hline & & & Leaf & Pseu & Root \\
\hline Fertilization method (FM) & $0.4303 \mathrm{~ns}$ & $0.0054^{*}$ & $0.0085^{*}$ & 0.16 & $0.0411^{*}$ \\
\hline Substrate particle size (SuPS) & $0.7152 \mathrm{~ns}$ & $0.0179^{*}$ & $0.0075^{*}$ & 0.26 & $0.0494^{*}$ \\
\hline $\mathrm{FM} \times \mathrm{SuPS}$ & $0.1910 \mathrm{~ns}$ & $0.0766 \mathrm{~ns}$ & 0.3135 & 0.2 & $.0586 \mathrm{~ns}$ \\
\hline
\end{tabular}

${ }^{*}=p$-value $\leq 0.05$ is statistically significant; $\mathrm{n} s=p$-value $\geq 0.05$ is not statistically significant

Significant interaction effects on growth parameters. The greatest number of leaves (10.3) was observed in plants treated with the fertilization method FIW + FF established in the LPS substrate, which was statistically comparable to that observed in plants treated with FF and established in the LPS substrate. Regardless of the fertilization method, the use of substrate with SPS led to a lower number of leaves per plant (Figure 1).

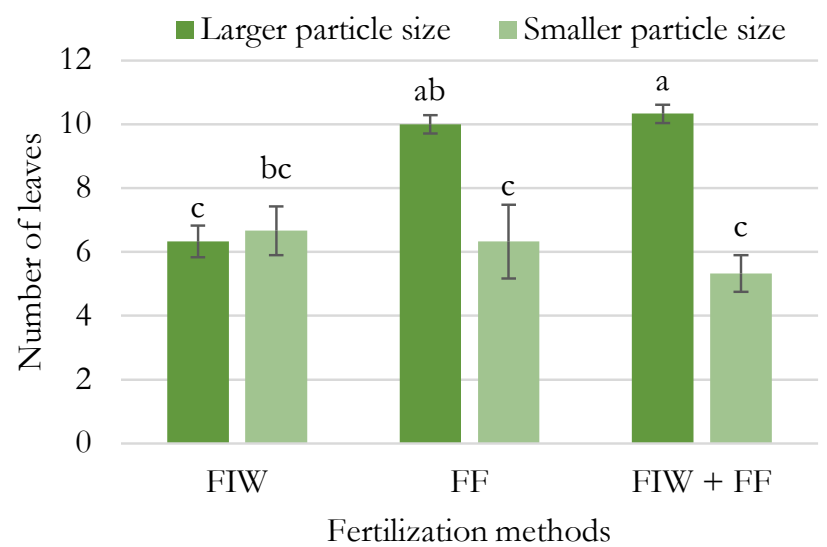

Figure 1. Number of leaves of Laelia anceps subsp. anceps plants as affected by different fertilization methods and substrate particle sizes

FIW: Fertilization in irrigation water; FF: Foliar fertilization. Bars with different letters + SD indicate significant statistical differences (Tukey, $p \leq 0.05$ )

Significant main effects of fertilization methods on growth parameters. The number of pseudobulbs (6.0), leaf area $\left(144.8 \mathrm{~cm}^{2}\right)$, and dry leaf biomass $(3.2 \mathrm{~g})$ showed the highest means in plants treated with FIW, followed by plants treated with FF, without statistical differences between these two application methods. In all three variables mentioned above, plants treated with the combination of fertilization methods (FIW $+\mathrm{FF}$ ) displayed the lowest means, though these means were statistically similar to those observed in plants treated with FF. Root volume was higher in plants with both FIW $\left(24.3 \mathrm{~cm}^{3}\right)$ and FF $\left(22.8 \mathrm{~cm}^{3}\right)$ fertilization methods, which statistically surpassed FIW + FF (Figure 2). Dry biomass weight displayed no significant differences among treatments, though the lowest numerical mean was observed in plants exposed to FIW + FF. 


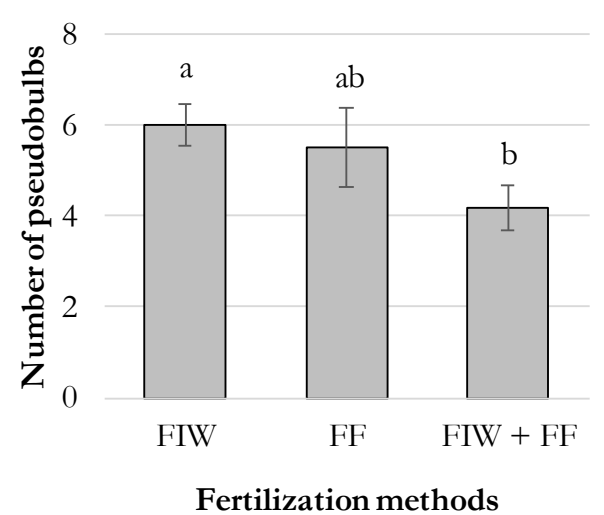

(A)

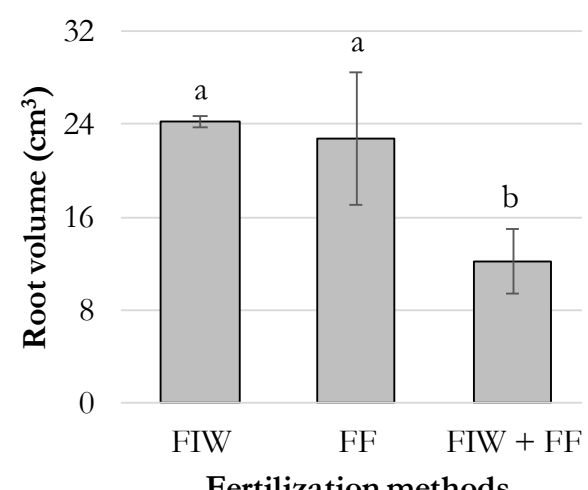

Fertilization methods

(C)

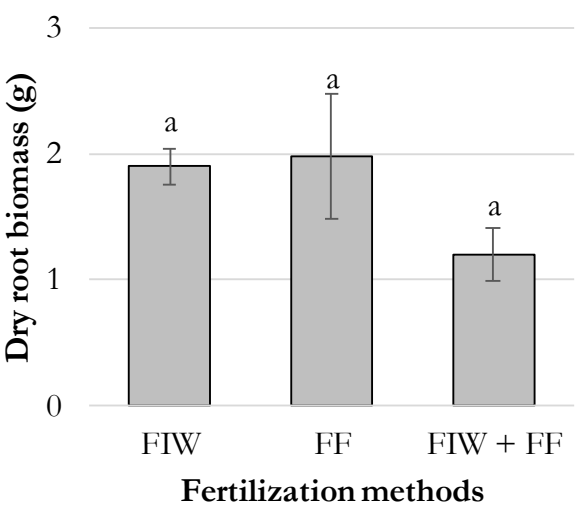

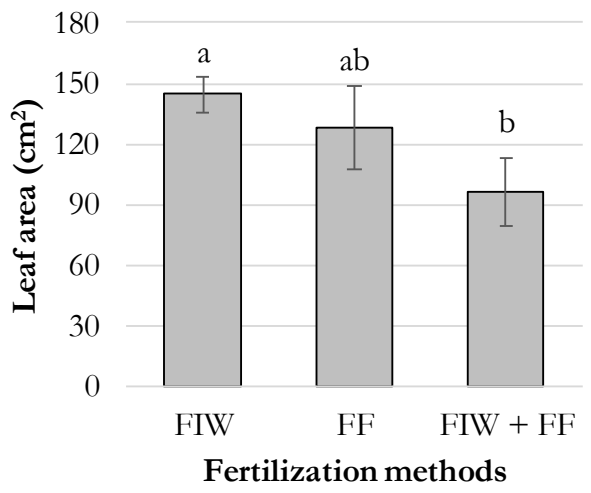

(B)

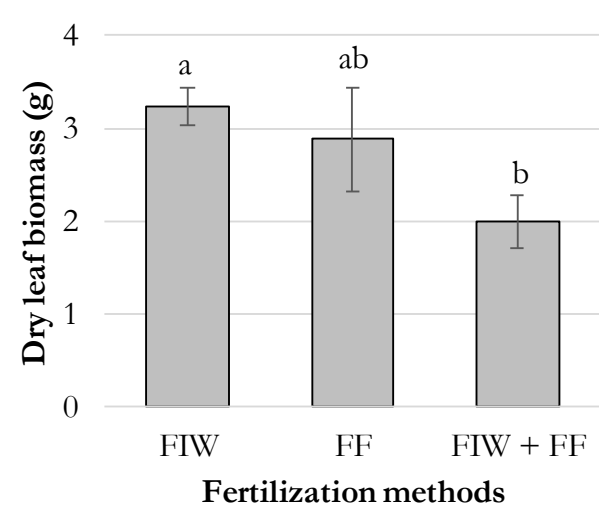

(D)

\section{(E)}

Figure 2. Number of pseudobulbs (A), leaf area (B), root volume (C), dry leaf biomass (D), and dry root biomass (E) of Laelia anceps subsp. anceps plants as affected by different fertilization methods FIW: Fertilization in irrigation water; FF: Foliar fertilization. Bars with different letters + SD indicate significant statistical differences (Tukey, $p \leq 0.05$ )

Significant main effects of particle size of the substrate on growth parameters. LPS in the substrate increased leaf area, root volume, dry leaf and root biomass by $39.7 \%, 44.8 \%, 38.7 \%$, and $36.3 \%$, respectively, compared to the values recorded in the substrate with SPS (Figure 3). 


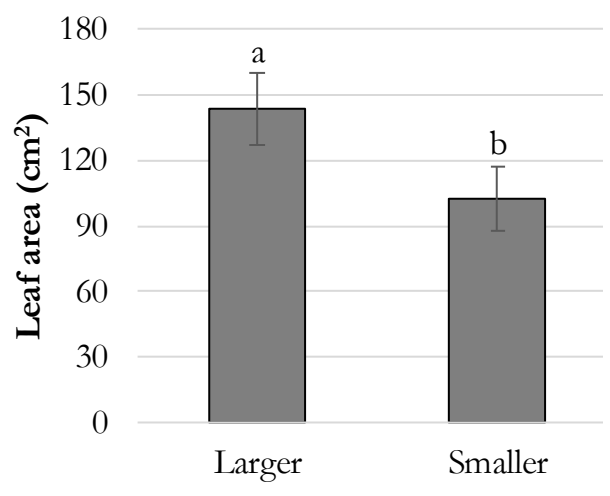

Substrate particle size

(A)

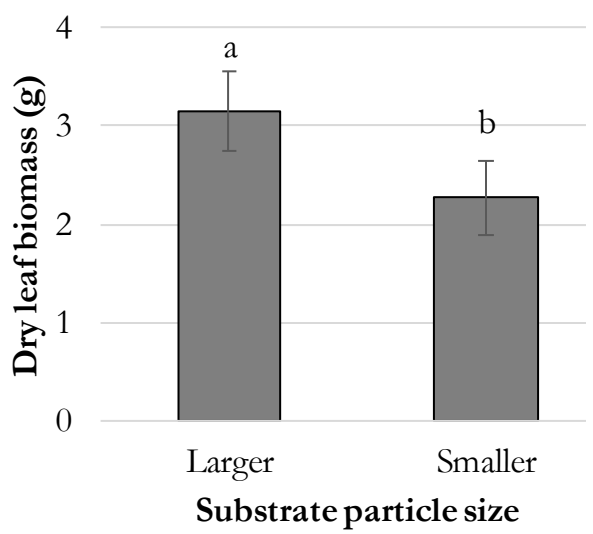

(C)

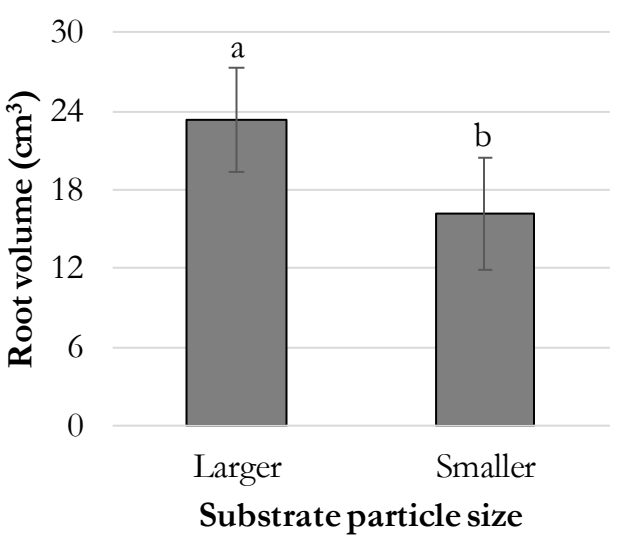

(B)

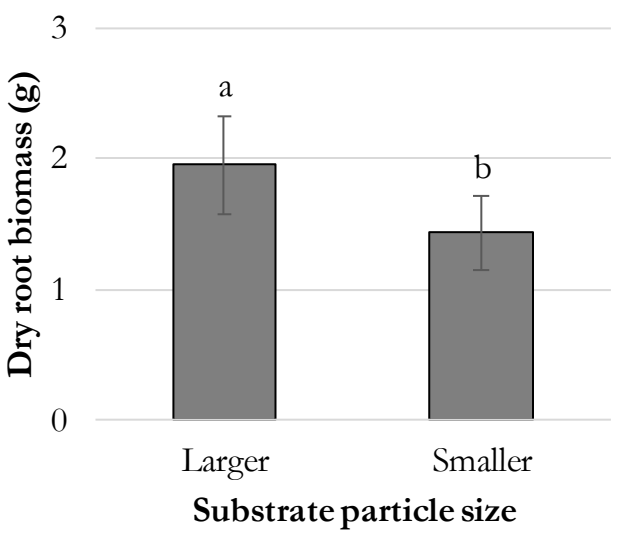

(D)

Figure 3. Leaf area (A), root volume (B), dry leaf biomass (C) and dry root biomass (D) of Laelia anceps subsp. anceps plants as affected by substrate particle size

Bars with different letters + SD indicate significant statistical differences (Tukey, $p \leq 0.05$ )

\section{Macronutrient status}

Interaction of the study factors was only significant on the concentrations of $\mathrm{P}, \mathrm{K}, \mathrm{Mg}$, and $\mathrm{S}$ in the roots. The fertilization method influenced the concentration of $S$ in pseudobulbs, and that of $\mathrm{P}, \mathrm{K}, \mathrm{Mg}$, and $\mathrm{S}$ in roots. The main effect of the particle size in the substrate was significant in the foliar concentrations of $\mathrm{K}$ and $S$ in the leaves and in the concentrations of $\mathrm{P}, \mathrm{K}, \mathrm{Ca}, \mathrm{Mg}$, and $\mathrm{S}$ in pseudobulbs (Table 4).

Significant interaction effects on macronutrient status. In roots, regardless of the particle size in the substrate, $\mathrm{K}, \mathrm{Mg}$, and $\mathrm{S}$ showed higher concentrations $\left(2.02,5.69\right.$, and $5.16 \mathrm{~kg}^{-1}$, respectively) with the combination of FIW + FF (Figures 4B-4D). P was higher in FIW and LPS (1.51 $\mathrm{g} \mathrm{kg}^{-1}$; Figure 4A). Except for this concentration of $\mathrm{P}$ in LPS, it was observed that, with both substrate particle sizes, FIW and FF applied individually caused the lowest concentrations of $\mathrm{P}, \mathrm{K}, \mathrm{Mg}$, and $\mathrm{S}$ (Figures 4A-4D). 
Table 4. Statistical significance $(p)$ of the study factors, fertilization method and particle size in the substrate, as well as their interaction, on concentrations of macronutrients in leaves, pseudobulbs, and roots of Laelia anceps subsp. anceps plants

\begin{tabular}{|c|c|c|c|c|c|c|}
\hline \multicolumn{7}{|c|}{ Leaf } \\
\hline Variation source & $\mathrm{N}$ & $\mathrm{P}$ & $\mathrm{K}$ & $\mathrm{Ca}$ & $\mathrm{Mg}$ & $S$ \\
\hline Fertilization method (FM) & $0.8460 \mathrm{~ns}$ & $0.5536 \mathrm{~ns}$ & $0.3024 \mathrm{~ns}$ & $0.2036 \mathrm{~ns}$ & $0.0505 \mathrm{~ns}$ & $0.6239 \mathrm{~ns}$ \\
\hline Substrate particle size (SuPS) & $0.4442 \mathrm{~ns}$ & $0.1643 \mathrm{~ns}$ & $0.0440^{*}$ & $0.1328 \mathrm{~ns}$ & $0.0825 \mathrm{~ns}$ & $0.0438^{*}$ \\
\hline $\mathrm{FM} \times \mathrm{SuPS}$ & $0.7844 \mathrm{~ns}$ & $0.5026 \mathrm{~ns}$ & $0.5464 \mathrm{~ns}$ & $0.4130 \mathrm{~ns}$ & $0.5605 \mathrm{~ns}$ & $0.7418 \mathrm{~ns}$ \\
\hline \multicolumn{7}{|c|}{ Pseudobulb } \\
\hline Variation source & $\mathrm{N}$ & $\mathrm{P}$ & $\mathrm{K}$ & $\mathrm{Ca}$ & $\mathrm{Mg}$ & $S$ \\
\hline Fertilization method (FM) & $0.6931 \mathrm{~ns}$ & $0.0654 \mathrm{~ns}$ & $0.0570 \mathrm{~ns}$ & $0.1567 \mathrm{~ns}$ & $0.1838 \mathrm{~ns}$ & $0.0179^{*}$ \\
\hline Substrate particle size (SuPS) & $0.6633 \mathrm{~ns}$ & $0.0444^{*}$ & $0.0005^{*}$ & $0.0299^{*}$ & $0.0194^{*}$ & $0.0386^{*}$ \\
\hline $\mathrm{FM} \times \mathrm{SuPS}$ & $0.7662 \mathrm{~ns}$ & $0.7872 \mathrm{~ns}$ & $0.9056 \mathrm{~ns}$ & $0.2605 \mathrm{~ns}$ & $0.1453 \mathrm{~ns}$ & $0.0585 \mathrm{~ns}$ \\
\hline \multicolumn{7}{|c|}{ Root } \\
\hline Variation source & $\mathrm{N}$ & $\mathrm{P}$ & $\mathrm{K}$ & $\mathrm{Ca}$ & $\mathrm{Mg}$ & $S$ \\
\hline Fertilization method (FM) & $0.0984 \mathrm{~ns}$ & $<0.0001^{*}$ & $<0.0001^{*}$ & $0.5587 \mathrm{~ns}$ & $0.0002^{*}$ & $<0.0001^{*}$ \\
\hline Substrate particle size (SuPS) & $0.7755 \mathrm{~ns}$ & $0.0002^{*}$ & $0.0727 \mathrm{~ns}$ & $0.0018^{*}$ & $0.3052 \mathrm{~ns}$ & $0.4973 \mathrm{~ns}$ \\
\hline $\mathrm{FM} \times \mathrm{SuPS}$ & $0.9790 \mathrm{~ns}$ & $0.0005^{*}$ & $0.0048^{*}$ & $0.0883 \mathrm{~ns}$ & $0.0283^{*}$ & $<0.0001^{*}$ \\
\hline
\end{tabular}

${ }^{*}=p$-value $\leq 0.05$ is statistically significant; $\mathrm{ns}=p$-value $\geq 0.05$ is not statistically significant

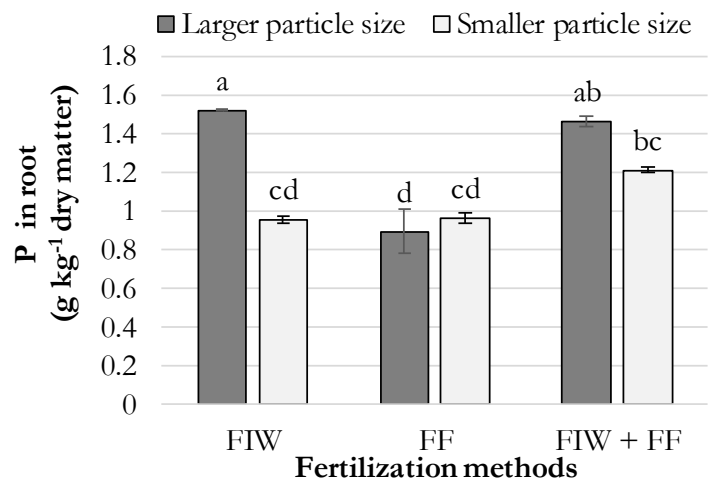

(A)

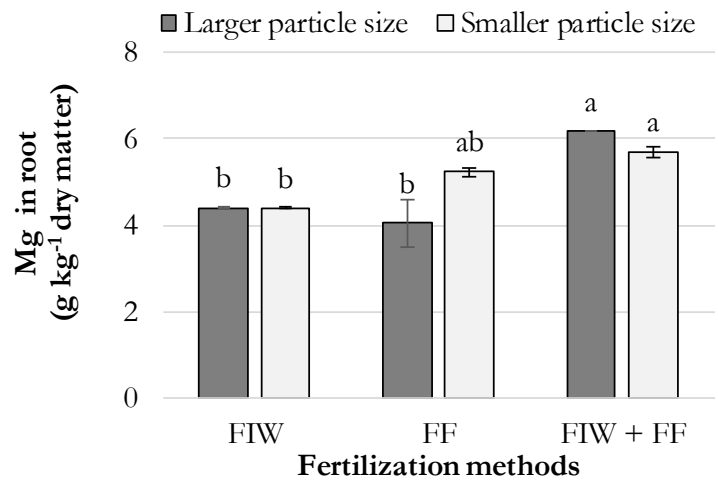

(C)

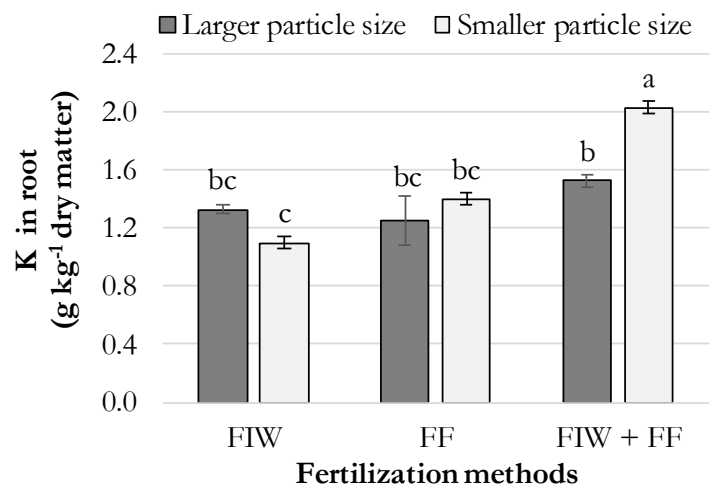

(B)

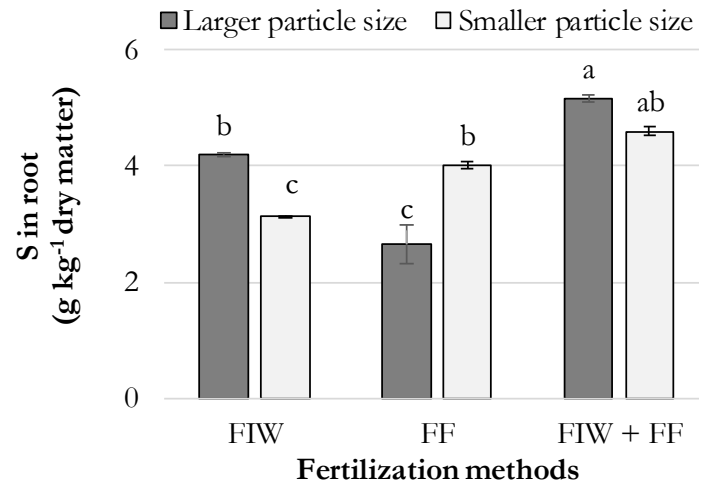

(D)

Figure 4. Concentrations of $\mathrm{P}(\mathrm{A}), \mathrm{K}(\mathrm{B}), \mathrm{Mg}(\mathrm{C})$, and $\mathrm{S}(\mathrm{D})$ in roots of Laelia anceps subsp. anceps plants as affected by different fertilization methods and substrate particle sizes

FIW: Fertilization in irrigation water; FF: Foliar fertilization. Bars with different letters + SD indicate significant statistical differences (Tukey, $p \leq 0.05$ )

Significant main effects of fertilization methods on macronutrient status. The fertilization methods influenced the concentration of $S$ in pseudobulbs (Figure 5), where FIW and FIW + FF exceed the concentration obtained with FF by $29 \%$ and $30.6 \%$, respectively. 


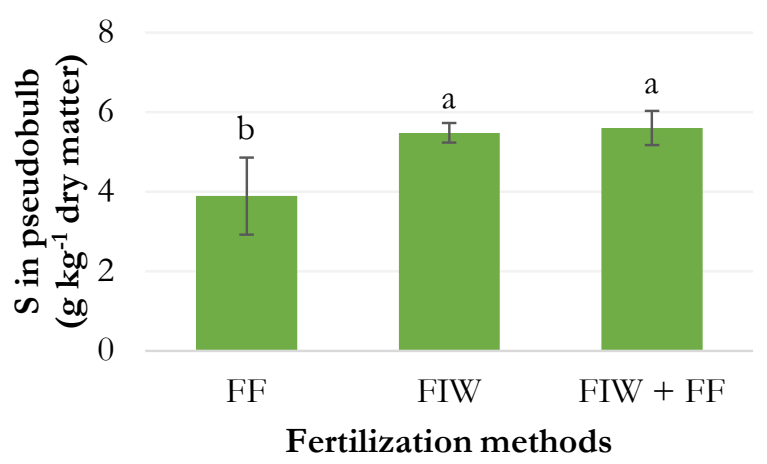

Figure 5. Concentration of $S$ in pseudobulbs of Laelia anceps subsp. anceps plants as affected by different fertilization methods

FIW: Fertilization in irrigation water; FF: Foliar fertilization. Bars with different letters + SD indicate significant statistical differences (Tukey, $p \leq 0.05$ )

Significant main effects of substrate particle size on macronutrient status. The main effect of substrate particle size was its influence on the concentrations of $\mathrm{K}$ and $\mathrm{S}$ in leaves (Figures 6A and 6B); in both, these were higher with SPS substrate by 28.5 and $26.4 \%$ respectively, compared to those obtained with LPS. This same trend was observed in the concentrations of $\mathrm{P}, \mathrm{K}, \mathrm{Ca}, \mathrm{Mg}$, and $\mathrm{S}$ in pseudobulbs $(27.7,62.4,28.7,31.6$, and $24.3 \%$, respectively; Figures $6 \mathrm{C}-6 \mathrm{G}$ ).

\section{Discussion}

\section{Aerial and root growth}

The interaction effects of the FM and SuPS significantly affected the number of leaves (Table 3), where FIW + FF with LPS resulted in the highest mean for this quantitative attribute measured (Figure 1). The rest of the variables measured were not affected by this interaction (Table 3). Similarly, Wang and Gregg (1994) did not find significant differences in the interaction between substrate mixtures and fertilization rates in Phalaenopsis [P. arnabilis (L.) Blume x P. Mount Kaala 'Elegance']. On the contrary, Osorio et al. (2014) reported a highly significant interaction between substrates and fertilization used in the growth of vanilla (Vanilla planifolia Jacks). Therefore, the interaction effects between substrates and fertilization regimes may depend on the genotypes.

Likewise, the main effects of FM and SuPS affected variables of aerial, root and dry biomass growth (Table 3). The FIW treatment registered the highest number of pseudobulbs, leaf area, root volume, and dry biomass of leaves and roots, with statistically similar means as those observed with FF (Figures 2A-D). In Phalaenopsis Sogo Yukidian 'V3' plants, $\mathrm{N}$ uptake can be done through the leaves and roots, though they have a better absorption efficiency through the roots, and better translocation when absorbed through the leaves (Susilo et al., 2013). However, according to Wang and Chang (2017), the amount of nutrients absorbed through the leaves in Phalaenopsis is limited and therefore it does not promote vegetative growth or flowering, the roots being the main organ responsible for nutrient uptake. When comparing different ratios of nitrogen sources $\left(\mathrm{NH}_{4}^{+}\right.$and $\left.\mathrm{NO}_{3}{ }^{-}\right)$in Dendrobium Sonia 'EarSakul', via leaves and roots, Ruamrungsri et al. (2014) reported that the 100:100 $\mathrm{mg} \mathrm{L}^{-1} \mathrm{~N}$ combination applied to the leaves promoted growth and greater ionic absorption, which differs from our results (Figure 2). Likewise, in Phalaenopsis Taisuco Swan and Phalaenopsis Pink Chiffon, foliar fertilization was favourable, and at a concentration of 0.10 to $0.16 \mathrm{~g} \mathrm{~L}^{-1} \mathrm{~N}$, plant biomass increased and optimal concentration of $\mathrm{N}\left(23-28 \mathrm{~g} \mathrm{~kg}^{-1}\right)$ was observed (Mantovani et al., 2015). Herein, we observed that FF applied individually favours the development of roots to a greater extent (root volume; Figure 
2C) than the aerial part of the plant. However, the aerial growth parameters remained statistically similar both in plants treated with FIW and FIW + FF. This species possesses coriaceous and fleshy leaves (Halbinger and Soto, 1997), and has been classified as a thick leaf orchid, characterized by thick cell walls, as well as the presence of cuticles and CAM metabolism (Hew and Yong, 2004; Zhang et al., 2018). In spite of those leaf features, nutrient absorption can take place through this organ, which stimulates root growth. Conversely, foliar fertilization of Cymbidium sp. plants resulted in higher nutrient accumulation in pseudobulbs two hours after spraying the leaves, thus representing an efficient method of nutrient supply (García-Gaytán et al., 2013).

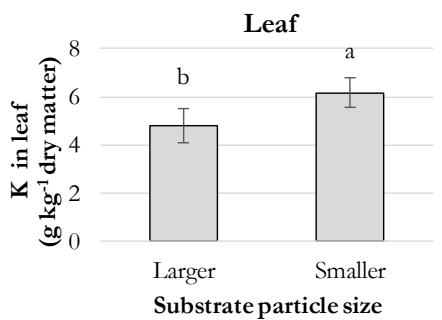

(A)

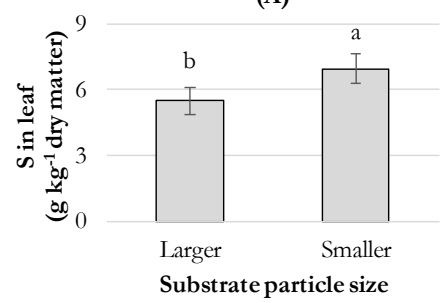

(B)

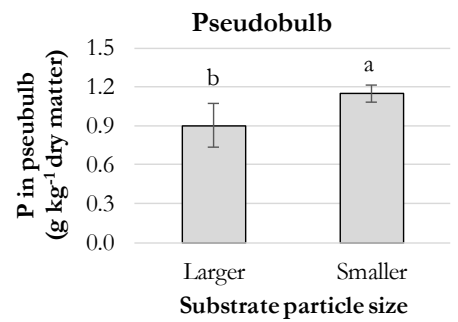

(C)

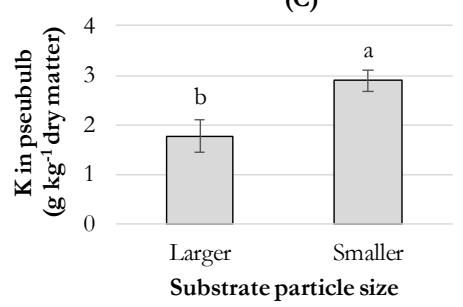

(D)

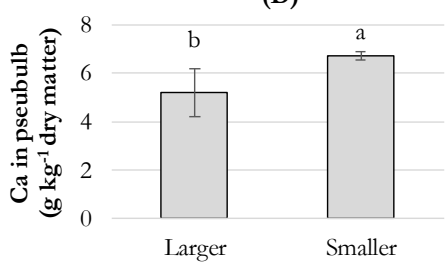

Substrate particle size

(E)

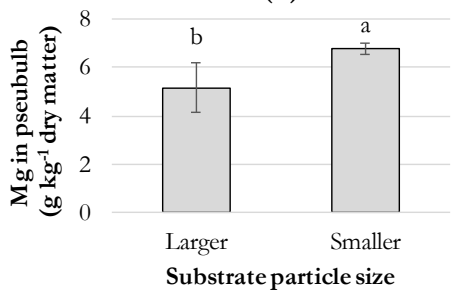

(F)

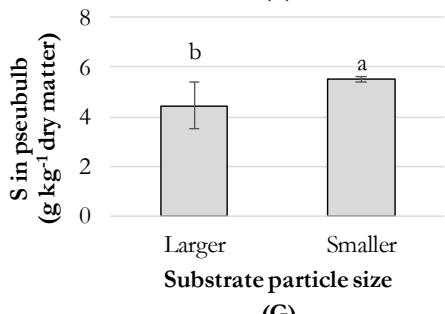

(G)

Figure 6. Concentrations of $\mathrm{K}(\mathrm{A})$ and $\mathrm{S}(\mathrm{B})$ in leaves, and of $\mathrm{P}(\mathrm{C}), \mathrm{K}(\mathrm{D}), \mathrm{Ca}(\mathrm{E}), \mathrm{Mg}(\mathrm{F})$, and $\mathrm{S}(\mathrm{G})$ in pseudobulbs of Laelia anceps subsp. anceps plants from the effect of substrate particle size Bars with different letters $+\mathrm{SD}$ indicate significant statistical differences (Tukey, $p \leq 0.05$ ) 
Unbalanced $\mathrm{N}$ supply, either in excess or deficiency, results in lower values of dry matter in Phalaenopsis plants (Mantovani et al., 2015). Complementarily, Lichty et al. (2015) reported that the higher the fertigation (more than three times a week) in Oncidium Miltassa Shelob 'Tolkien', the lower the water holding capacity and growth of the orchids. Under our experimental conditions, the concentration, amount, and frequency of application for both types of fertilization were the same. Nevertheless, the foliar method by itself is sufficient and does not require alternating with fertilization via substrate, which results in deleterious effects such as less dry matter production.

Regarding the substrate particle size effects on growth parameters, LPS resulted in greater leaf area, root volume, and accumulation of dry leaf and root biomass (Figure 3). These results are positively associated with the highest $\mathrm{N}, \mathrm{P}$, and $\mathrm{K}$ concentrations and the highest $\mathrm{CEC}$ value in this substrate rather than in the substrate with SPS (Table 2).

\section{Nutrient status}

Under our experimental conditions, the concentration of $\mathrm{N}$ in both of the organs analysed was not affected by the treatments tested. In 2-year-old plants of the same species treated with $225 \mathrm{mg} \mathrm{L}^{-1} \mathrm{~N}$, higher concentrations of $\mathrm{N}$ in leaves, pseudobulbs, and roots $\left(15,10\right.$, and $25 \mathrm{~g} \mathrm{~kg}^{-1}$, respectively) were observed (Tejeda-Sartorius et al., 2018), as compared to our results $\left(9,6\right.$, and $7 \mathrm{~g} \mathrm{~kg}^{-1} \mathrm{~N}$ in leaves, pseudobulbs, and roots, respectively) in 3-year-old plants. In the present study, our fertilizer (Peters ${ }^{\circ}$ Professional 30-10-10) contained urea as the main source of $\mathrm{N}$. Thus, from the $30 \%$ of total $\mathrm{N}$ supplied by our fertilizer, $24.8 \%$ was in the form of urea, so that the $\mathrm{NH}_{4}{ }^{+}: \mathrm{NO}_{3}$ ratio was high. In general, nitrate uptake rates in some terrestrial and epiphytic orchids are much lower than those of most crops (Hew et al., 1993). Furthermore, Laelia speciosa preferentially absorbs more $\mathrm{NH}_{4}{ }^{+}$than $\mathrm{NO}_{3}{ }_{3}^{-}$from the nutrient solution under higher nitrogen doses (Díaz-Álvarez et al., 2015). In Dendrobium Sonia 'EarSakul', the absorption of $\mathrm{NH}_{4}{ }^{+}$as the sole source of $\mathrm{N}$ through the roots was very high, though the translocation to the leaves and pseudobulbs was lower as compared to the application through the leaves (Ruamrungsri et al., 2014). Similarly, Phalaenopsis Blume $\times$ Taisuco Kochdian does not grow well with $100 \% \mathrm{~N}^{-\mathrm{NH}_{4}}{ }^{+}$, requiring an adequate input of $\mathrm{N}^{-\mathrm{NO}_{3}}{ }^{-}$(no less than $50 \%$, preferably $75 \%$ of the total $\mathrm{N}$ supply) in order to improve growth and flowering (Wang, 2008). Thus, application methods, sources and levels of $\mathrm{N}$ supply would result in different responses depending on the genotype tested. Moreover, developmental stages of the plants would also affect the ultimate response of the genotype to $\mathrm{N}$ supply (Zhang et al., 2018).

The interaction of the study factors (FM and SuPS) significantly influenced the nutritional concentrations of $\mathrm{P}, \mathrm{K}, \mathrm{Mg}$, and $\mathrm{S}$ in roots (Table 4), where $\mathrm{FF}$ had a negative effect on the concentrations of these macronutrients, regardless of the particle size of the substrate (Figure 4). The concentration of $P$ in roots was higher in treatments with FIW and FIW + FF with LPS (Figure 4A); the concentration of $\mathrm{K}$ and $\mathrm{Mg}$ showed differences in roots and was higher when SPS and FIW + FF were used (Figures 4B and 4C). In root tissues of Phalaenopsis Tanigawa X Yukimai Dream 'KS 370' and 'KS 352', the concentrations of P, K, Ca, Mg, and $\mathrm{Fe}$ were positively correlated with the increase in the ionic strength of the nutrient solution (Hwang et al., 2009). Under our experimental conditions, the root nutrient concentrations from the interaction effect may be related to the low absorption of nutrients in orchids (Zhang et al., 2018) and the root structure in which the velamen plays an important role in nutrient uptake in the epiphytic habit of orchids (Zotz and Winkler, 2013). Charged ions are retained in the velamen, probably due to positive and negative charges on the cell walls, while uncharged compounds are lost to the external environment. Furthermore, nutrient absorption follows biphasic kinetics with a highly efficient active transport system at low external concentrations. However, epiphytes, including orchids, have restrictions on the physiological absorption of nutrients, including nitrogen (Silva Júnior et al., 2013).

Regarding the main effect of the fertilization method, $S$ concentration in pseudobulbs was the highest in plants treated with FIW and FIW + FF (Figure 5). Concerning the main effect of SuPS, plants established in SPS displayed higher concentrations of $\mathrm{K}$ and $\mathrm{S}$ in leaves (Figures $6 \mathrm{~A}$ and $6 \mathrm{~B}$ ), and of $\mathrm{P}, \mathrm{K}, \mathrm{Ca}, \mathrm{Mg}$, and $\mathrm{S}$ in 
pseudobulbs (Figures 6C-6G). Likewise, Wang and Konow (2002) reported higher levels of N, P, and K, but similar levels of $\mathrm{Ca}$ and $\mathrm{Mg}$ for Phalaenopsis Blume leaves grown on fine grade Douglas fir bark as compared to the control. Similarly, in Cymbidium 'Baltic Glacier Mint Ice', different mixtures of growing media, nutrition and growth regulators resulted in higher concentrations of $\mathrm{N}, \mathrm{P}$, and $\mathrm{K}$ in leaves and pseudobulbs, which favoured the quality of the subsequent flowering of the hybrid (Barman and Naik, 2017).

As mentioned above, the highest concentrations of $\mathrm{K}$ and $\mathrm{S}$ in leaves (Figures $6 \mathrm{~A}$ and $6 \mathrm{~B}$ ) were obtained in the substrate with SPS, where a dilution effect could be assumed given that SPS significantly decreased the dry biomass of leaves (Figure 3C). The effects on the $\mathrm{P}$ and $\mathrm{K}$ concentrations in leaves may be more evident in reproductive stages of orchids (Wang, 2010). However, in our study, SuPS significantly affected P and K in juvenile (non-reproductive) Laelia anceps pseudobulbs and roots, elements that could be available in the flowering stages of the species.

In our study, the substrate with SPS increased the concentrations of $\mathrm{P}, \mathrm{K}, \mathrm{Ca}, \mathrm{Mg}$, and $\mathrm{S}$ in pseudobulbs (Figure 6). This could be attributed to greater contact of the roots with a substrate with higher percentages of readily available water, easily available water, and reserve water (Table 2 ), which would promote greater nutrient absorption by the roots. Furthermore, a better water status in the plant also favours absorption through the leaves (Berry et al., 2019), as well as the transport of nutrients (Nieves-Cordones et al., 2019) to storage organs such as pseudobulbs, from where nutrients can be translocated to demand organs in the subsequent growth phases. Higher stem growth and faster flowering of Doritaenopsis Queen Beer 'Mantefon' were found in plants established with peat moss, attributing such result to a better contact of the roots with the substrate, which allowed an adequate supply of water and nutrients (Kim et al., 2016). The composition of the medium affects the availability of water and nutrients for the growth of potted orchids. Therefore, fertigation programs must take medium composition into account (Lichty et al., 2015). Under our experimental conditions, the larger particle size stimulated plant growth. Nonetheless, since there was a higher concentration of some nutrients in reserve organs such as pseudobulbs (in a medium with smaller particle size), these reserves would be useful in the further development of the plant, enabling it to achieve an even faster reproductive maturity and better flowering quality.

In commercial orchid production systems, substrate mixtures can bring better conditions for plant growth, as compared with the use of single substrates such as bark. In Phalaenopsis 'Stripe' and 'White Red Lip', positive results in number of roots, total fresh weight and percentage of dry matter were found when using a mixture of perlite + expanded clayball + peat moss (Hwang and Jeong, 2007). In Cymbidium orchids, number and length of roots, as well as leaf length increased with the use of perlite alone or in combination with sand or coconut peat (Sedaghathoor et al., 2017). In Phalaenopsis 'Taisuco Kochdian', growth and flowering characteristics improved with the combination of pine bark with perlite and peat moss, adding a dose of 300 $\mathrm{mg} \mathrm{K} \mathrm{L}{ }^{-1}$ (Wang, 2007). In the present study, we tested the application of $300 \mathrm{mg} \mathrm{N} \mathrm{L}^{-1} \mathrm{~N}$ to plants established in substrate mixtures containing a combination of pine bark/perlite with different particle sizes. These treatments differentially affected plant growth and nutrient status. The substrate with LPS and FIW stimulated growth and nutrient concentrations, as compared to plants established in the substrate with SPS. Conversely, in Phalaenopsis, when using different proportions of pine bark with other materials of different particle size (such as peat moss, sphagnum moss, coconut husk chips) with a rate of $120 \mathrm{mg} \mathrm{L}^{-1} \mathrm{~N}$, no effects on growth were found (Amberger-Ochsenbauer, 2010). In our study, substrate particle size had a greater impact on the nutrient concentration than the fertilization method.

\section{Conclusions}

Fertilization in irrigation water (FIW) and large particle size (LPS) of the substrate significantly increased the number of leaves of Laelia anceps subsp. anceps. In general, the individual application of either FIW or foliar fertilization (FF) stimulated growth parameters and biomass production. Conversely, the 
combination FIW + FF applied to plants established in the substrate with smaller particle size (SPS) negatively affected growth parameters. With all of the $\mathrm{N}$ application methods, there was no significant effect of its concentration on the analysed organs. The interaction of factors was significant for $\mathrm{P}, \mathrm{K}, \mathrm{Mg}$, and $\mathrm{S}$ in the roots. The substrate with SPS resulted in a higher foliar concentration of $\mathrm{K}$ and $\mathrm{S}$, as well as of $\mathrm{P}, \mathrm{K}, \mathrm{Ca}, \mathrm{Mg}$, and $\mathrm{S}$ in pseudobulbs. We are currently carrying out further studies on the impact of foliar fertilization in a broader range of developmental stages, as well as other forms and combinations of $\mathrm{N}$ supply in this species.

\section{Authors' Contributions}

Conceptualization: OTS, LITT; Methodology: OTS, LITT, MGPS; Validation: LITT; Formal analysis: OTS, YLFP, MGPS; Investigation; OTS, LITT; Resources; OTS, LITT; Writing-original draft: OTS; Writing-review and editing: LITT, MGPS, YLFP; Supervision: OTS, LITT; Project administration: LITT. All authors read and approved the final manuscript.

\section{Acknowledgements}

The authors thank the Laboratory of Plant Nutrition at the College of Postgraduates in Agricultural Sciences, Campus Montecillo, for the space and infrastructure facilities used to perform the plant nutrient analyses.

\section{Conflict of Interests}

The authors declare that there are no conflicts of interest related to this article.

\section{References}

Alcántar GG, Sandoval MV (1999). Manual de análisis químico de tejido vegetal. Guía de muestreo, preparación, análisis e interpretación. Publicación Especial de la Sociedad Mexicana de la Ciencia del Suelo A. C. Chapingo, México.

Amberger-Ochsenbauer S (2010). Evaluation of growing media components for Phalaenopsis. Acta Horticulturae 878:355-360. https://doi.org/10.17660/ActaHortic.2010.878.44

Barman D, Naik SK (2017). Effect of substrate, nutrition and growth regulator on productivity and mineral composition of leaf and pseudobulb of Cymbidium hybrid "Baltic Glacier Mint Ice”. Journal of Plant Nutrition 40:784-794. https://doi.org/10.1080/01904167.2016.1201496

Berry ZC, Emery NC, Gotsh SG, Goldsmith GR (2019). Foliar water uptake: processes, pathways, and integration into plant water budgets. Plant, Cell \& Environment 42:410-423. https://doi.org/10.1111/pce.13439

Bremner JM (1965). Total nitrogen. In Black CA (Ed). Methods of soil analysis. Part 2. Agronomy 9. American Society of Agronomy. Madison, WI, USA. pp 1149-1178.

Chase MW, Cameron KM, Freudenstein JV, Pridgeon AM, Salazar G, Van den Berg C, Schuiteman A (2015). An updated classification of Orchidaceae. Botanical Journal of the Linnean Society 177:151-174.

Díaz-Álvarez EA, Lindig-Cisneros R, de la Barrera E (2015). Responses to simulated nitrogen deposition by the neotropical epiphytic orchid Laelia speciosa. PeerJ 3:e1021. https://doi.org/10.7717/peerj.1021

Dressler RL (2005). How many orchid species? Selbyana 26:155-158.

Fageria NK, Barbosa MP, Moreira A, Guimarães (2009). Foliar fertilization of crop plants. Journal of Plant Nutrition 32:1044-1064. https://doi.org/10.1080/01904160902872826 
García-Gaytán V, Valdovinos-Ponce G, Rodríguez-Mendoza MN, Pedraza-Santos ME, Trejo-Téllez LI, Soto-Hernández M (2013). Rutas de la penetración foliar en la fertilización de la orquídea Cymbidium sp. (Orchidaceae). Revista Mexicana de Ciencias Agrícolas Pub Esp:913-924.

Halbinger F, Soto M (1997). Laelias of Mexico. Orquídea (Mex). Herbario AMO, México.

Haytova D (2013). A review of foliar fertilization of some vegetables crops. Annual Review \& Research in Biology 3(4):455-465.

Hew CS, Lim LY, Low CM (1993). Nitrogen uptake by tropical orchids. Environmental and Experimental Botany 33(2):273-281. https://doi.org/10.1016/0098-8472(93)90073-O

Hew CS, Yong WH (2004). The physiology of tropical orchids in relation to the industry. 2nd Ed. World Scientific, New Jersey.

Hwang SJ, Jeong BR (2007). Growth of Phalaenopsis plants in five different potting media. Journal of the Japanese Society of Horticultural Science 76(4):319-326.

Hwang SJ, Sivanesan I, Jeong BR (2009). Short-term ion uptake by Phalaenopsis as affected by concentration of the solution. Journal of Plant Nutrition 32(12):2044-2061. https://doi.org/10.1080/01904160903308143

Kannan S (2010). Foliar fertilization for sustainable crop production. In Lichtfouse E (Ed). Genetic engineering, biofertilisation, soil quality and organic farming. Sustainable Agriculture Reviews 4. Springer, Netherlands, pp 371-402. https://doi.org/10.1007/978-90-481-8741-6_13

Kim HJ, Kim J, Yun DL, Kim KS, Kim YJ (2016). Growth and flowering of Doritaenopsis Queen Beer "Mantefon” as affected by different potting substrates. The Horticulture Journal 85(4):360-365. https://doi.org/10.2503/hortj.MI-133

Lichty J, Singleton P, Kim HJ (2015). Substrates affect irrigation frequency and plant growth of potted orchids. Acta Horticulturae 1104:463-468. https://doi.org/10.17660/ActaHortic.2015.1104.66

Mantovani C, de Mello Prado R, Pivetta KFL (2015). Foliar diagnosis in Phalaenopsis orchid plants subjected to application of nitrogen. African Journal of Agricultural Research 10(53):4906-4912. https://doi.org/10.5897/AJAR2015.9921

Mengel K (2002). Alternative or complementary role of foliar supply in mineral nutrition. Acta Horticulturae 594:33-47. https://doi.org/10.17660/ActaHortic.2002.594.1

Naasz R, Caron J, Legault J, Pichette A (2009). Efficiency factors for bark substrates: Biostability, aeration, or phytotoxicity. Soil Science Society of America Journal 73(3):780-791. https://doi.org/10.2136/sssaj2008.0058

Nieves-Cordones M, García-Sánchez F, Pérez-Pérez JG, Colmenero-Flores JM, Rubio F, Rosales MA (2019). Coping with water shortage: An update on the role of $\mathrm{K}^{+}, \mathrm{Cl}^{-}$, and water membrane transport mechanisms on drought resistance. Frontiers in Plant Science 10:1619. https://doi.org/10.3389/fpls.2019.01619

Osorio AI, Osorio-Vega NW, Diez MC, Moreno FH (2014). Nutrient status and vegetative growth of Vanilla planifolia Jacks plants as affected by fertilization and organic substrate composition. Acta Agronómica 63(4):326-334. https://doi.org/10.15446/acag.v63n4.40754

Ruamrungsri S, Khuankaew T, Ohyama T, Sato T (2014). Nitrogen sources and its uptake in Dendrobium orchid by ${ }^{15} \mathrm{~N}$ tracer study. Acta Horticulturae 1025:207-211. https://doi.org/10.17660/ActaHortic.2014.1025.30

SAS (2011). SAS/STAT Users Guide. Version 9.3. SAS Institute Inc., Cary, N. C., USA.

Sedaghathoor S, Dehno GG, Naderi R, Kalatehjari S, Kaviani B (2017). Comparison of different media to produce Cymbidium orchids by pseudobulbs. Revista de Agricultura Neotropical 4:33-37.

Silva Júnior J, Rodrigues M, Castro EM, Bertolucci SK, Pasqual M (2013). Changes in anatomy and chlorophyll synthesis in orchids propagated in vitro in the presence of urea. Acta Scientiarum Agronomy 35(1):65-72. https://doi.org/10.4025/actasciagron.v35i1.15356

Slump K (2004). Predictions from the medium. Ingredients to use when making a potting mix for orchids. Orchids 73:416-418.

Susilo H, Peng Y-C, Lee S-C, Chen Y-C, Chang Y-CA (2013). The uptake and partitioning of nitrogen in Phalaenopsis Sogo Yukidian 'V3' as shown by ${ }^{15} \mathrm{~N}$ as a tracer. Journal of the American Society for Horticultural Science 138(3):229-237. https://doi.org/10.21273/JASHS.138.3.229

Tejeda-Sartorius O, Téllez-Velasco, MAA, Escobar-Aguayo JJ (2017). Estado de conservación de orquídeas silvestres (Orchidaceae). Agroproductividad 10(6):3-12.

Tejeda-Sartorius O, Trejo-Téllez LI, Téllez-Velasco MAA, Gómez-Merino FC (2018). Nutrient concentration in vegetative organs of the orchid Laelia anceps subsp. anceps based on mineral fertilization and biofertilization. The Horticultural Journal 87(4):541-548. https://doi.org/10.2503/hortj.OKD-148 
Trejo-Téllez LI, Rodríguez-Mendoza MN, Gómez-Merino FC, Alcántar-González G (2016). Fertilización foliar. In Alcántar-González G, Trejo-Téllez LI, Gómez-Merino FC (Eds). Nutrición de cultivos. Segunda edición, Guadalajara, México pp 281-317.

Wang YT (2007). Potassium nutrition affects Phalaenopsis growth and flowering. HortScience 42(7):1563-1567. https://doi.org/10.21273/HORTSCI.42.7.1563

Wang YT (2008). High $\mathrm{NO}_{3}-\mathrm{N}$ to $\mathrm{NH}_{4}-\mathrm{N}$ ratios promote growth and flowering of a hybrid Phalaenopsis grown in two root substrates. HortScience 43(2):350-353. https://doi.org/10.21273/HORTSCI.43.2.350

Wang YT (2010). Phalaenopsis mineral nutrition. Acta Horticulturae 878:321-333. https://doi.org/10.17660/ActaHortic.2010.878.41

Wang YT, Blanchard M, Lopez R, Runkle E (2007). Growing the best Phalaenopsis. Part 2: Media, transplanting, water and nutrient requirements. Orchids 76:106-111.

Wang YT, Chang YCA (2017). Effects of nitrogen and the various forms of nitrogen on Phalaenopsis Orchid - A review. HortTechnology 27(2):144-149. https://doi.org/10.21273/horttech03204-16

Wang YT, Gregg LL (1994). Medium and fertilizer affect the performance of Phalaenopsis orchids during two flowering cycles. HortScience 29(4):269-271. https://doi.org/10.21273/HORTSCI.29.4.269

Wang YT, Konow EA (2002). Fertilizer source and medium composition affect vegetative growth and mineral nutrition of a hybrid moth orchid. Journal of the American Society for Horticultural Science 127(3):442-447. https://doi.org/10.21273/JASHS.127.3.442

Zhang S, Yang Y, Li J, Qin J, Zhang W, Huang W, Hu H (2018). Physiological diversity of orchids. Plant Diversity 40(4):196-208. https://doi.org/10.1016/j.pld.2018.06.003

Zong-min M, Ning Y, Shu-yun L, Hong H (2012). Nitrogen requirements for vegetative growth, flowering, seed production, and ramet growth of Paphiopedilum armeniacum (Orchid). HortScience 47(5):585-588. https://doi.org/10.21273/HORTSCI.47.5.585

Zotz G, Winkler U (2013). Aerial roots of epiphytic orchids: the velamen radicum and its role in water and nutrient uptake. Oecologia 171:733-741. https://doi.org/doi:10.1007/s00442-012-2575-6
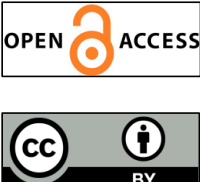

The journal offers free, immediate, and unrestricted access to peer-reviewed research and scholarly work. Users are allowed to read, download, copy, distribute, print, search, or link to the full texts of the articles, or use them for any other lawful purpose, without asking prior permission from the publisher or the author.

License - Articles published in Notulae Botanicae Horti Agrobotanici Cluj-Napoca are Open-Access, distributed under the terms and conditions of the Creative Commons Attribution (CC BY 4.0) License. (C) Articles by the authors; UASVM, Cluj-Napoca, Romania. The journal allows the author(s) to hold the copyright/to retain publishing rights without restriction. 